\title{
The feeding value of forage herbs: studies with red deer
}

\author{
S.O. HOSKIN, P.R. WILSON, M. ONDRIS and A.H. BUNOD \\ Institute of Veterinary, Animal and Biomedical Sciences, Massey University, PB11222, Palmerston North \\ S.O.Hoskin@massey.ac.nz
}

\begin{abstract}
This paper summarises three studies that: 1) compared the feeding value of perennial ryegrass-based pasture with chicory and plantain during 8 weeks grazing by weaner red deer in spring 2003 and 13 weeks grazing plantain by weaner deer during autumn 2004; 2), compared the liver copper, liver and serum vitamin B12 and blood selenium status of weaner red deer grazing ryegrass-based pasture, chicory or plantain for 8 weeks during spring 2003; and 3) determined the effect of grazing perennial ryegrass-based pasture alone, or with intermittent grazing of plantain from 1 month pre-partum to 1 month post-partum on liver copper and vitamin B12 status of calves during December 2004 and January 2005 . Feeding value (as determined by liveweight gain) of chicory was $40-48 \%$ higher than other forages in spring. Feeding value of plantain was $14 \%$ higher than pasture in autumn, but similar to pasture in spring. Grazing chicory significantly enhanced the liver copper concentration of weaner deer in spring compared with both ryegrass and plantain. Grazing plantain significantly enhanced the copper status of weaners in autumn, but not of weaners or calves in spring and early summer, enhanced the vitamin B12 status of weaners in autumn and spring and calves in early summer and increased the selenium status of weaners during both spring and autumn. This study has highlighted the complementary role of forage herbs in improving growth and maintaining trace element status of farmed deer.
\end{abstract}

Keywords: chicory, plantain, copper, vitamin B12, selenium, weaner deer

\section{Introduction}

Chicory (Cichorium intybus) produces a large quantity of high nutritive value herbage from spring through to autumn, has a high feeding value (determined by liveweight gain; Barry 1998), and is highly suited to deer production systems because seasonal growth is aligned with deer feed requirements. Previous research has also demonstrated enhanced liver copper $(\mathrm{Cu})$ status of weaner deer during autumn and spring (Barry et al. 2001; Wilson et al. 2003) and increased liver vitamin B12 and blood selenium (Se) concentrations during autumn (Wilson et al. 2003) of deer grazing chicory.

In comparison to wild deer, farmed deer in New Zealand appear to have a lower mineral status and may be at greater risk of mineral deficiencies, particularly copper (Reid et al. 1980; Tremain-Boone et al. 2001). This could be related to the restricted access of farmed deer to plant dietary constituents rich in minerals such as herbs and browse (Tremain-Boone et al. 2001). Copper deficiency, and in key locations cobalt (for vitamin B12), selenium and iodine deficiency are of increasing concern.

Narrow-leaved plantain (Plantago lanceolata cv. Ceres Tonic) is a forage herb possibly suitable for deer production due to a similar annual pattern of feed production to chicory and is also purported to have a high mineral content. However, no published data exist on the feeding value of plantain for farmed deer and no direct comparisons of the two readily commercially available forage herbs (chicory and plantain) appear available in the literature regarding any aspect of production or health of grazing ruminants.

The aims of these studies were (1) to compare the feeding value of perennial ryegrass-based pasture with chicory and plantain in spring and plantain in autumn and (2) to compare the copper, vitamin B12 and selenium status of weaner deer grazing ryegrass, chicory or plantain in spring, and (3) to determine the effect of grazing perennial ryegrass, or with intermittent grazing of plantain from 1 month pre-partum to 1 month postpartum, on copper and vitamin B12 status of deer calves.

\section{Materials and Methods \\ Experiment 1}

Between 30 September and 1 December 2003, 30 weaner deer on the Massey University Deer Research Unit were randomly allocated based on liveweight to grazing either permanent perennial ryegrass (Lolium perenne cv. Nui)based pasture ( $91 \%$ grass, $2 \%$ clover, $7 \%$ dead matter and $1 \%$ weed), chicory (cv. Grasslands Puna) sown spring 2000 as pure chicory (33\% chicory leaf, 5\% chicory reproductive stem, $28 \%$ clover, $12 \%$ dead matter and $22 \%$ weed (mostly pennyroyal and dock)) or narrowleaved plantain (cv. Ceres Tonic) sown spring 2002 (46\% plantain leaf, $25 \%$ plantain reproductive stem, $2 \%$ clover, $23 \%$ dead matter and $4 \%$ weed) until 1 December. Prior to the experiment, deer had been grazing ryegrass-based pasture together in one mob for 3 months. The ryegrass treatment comprised four paddocks ( 1.65 ha in total), chicory three paddocks (1.21 ha in total) and plantain three paddocks (1.90 ha in total), all of which were rotationally grazed. Including re-grazing on a rotation, 1.65 ha of ryegrass, 2.42 ha of chicory and 2.55 ha of 
plantain was grazed in total. Rotation length was 3 weeks for chicory and 4 weeks for plantain. For ryegrass, deer did not return to previously grazed paddocks within the timeframe due to excluding paddocks for calving.

Pre- and post- grazing herbage masses were determined from each paddock, together with sampling for feed on offer, by taking cuts to soil level from six quadrats $(0.1$ $\mathrm{m}^{2}$ ) per paddock. For each forage treatment, samples of feed on offer were mixed, two $200 \mathrm{~g}$ sub-samples were pooled and then stored at $-20^{\circ} \mathrm{C}$ for chemical and mineral analysis. Samples taken from quadrat cuts were dissected into botanical components and separately oven-dried $\left(100^{\circ} \mathrm{C}\right.$ for $\left.24 \mathrm{~h}\right)$ and weighed. Herbage allowances (excluding dead, reproductive stem and weed material) for all animals were set at $7 \mathrm{~kg}$ dry matter (DM) per deer per day.

Deer were weighed on a fortnightly basis to determine liveweight gain. At trial-start, liver biopsies were taken from sedated deer (Wilson 2000) and at trial-conclusion, liver samples were recovered following slaughter at Venison Packers Feilding Ltd for determining $\mathrm{Cu}$ status. Blood samples were taken by jugular venipuncture at the start and end of the trial for selenium and serum vitamin B12 concentration. Hot carcass weight data were obtained from Venison Packers Feilding.

\section{Experiment 2}

Between 12 March and 11 June 2004, 50 weaner deer were randomly allocated based on sex, genotype (red and $1 / 4$ wapiti hybrid) and liveweight to grazing either permanent perennial ryegrass-based pasture ( $70 \%$ grass, $4 \%$ clover, $22 \%$ dead matter and $4 \%$ weed) or the plantain used in Experiment 1 (45\% plantain leaf, $<1 \%$ plantain reproductive stem, $34 \%$ clover, $13 \%$ dead matter and $8 \%$ weed). Deer were rotationally grazed throughout the trial with herbage allowances (excluding dead, reproductive stem and weed material) for all animals being set at $5 \mathrm{~kg} \mathrm{DM} /$ deer/day. Deer allocated to the plantain treatment grazed permanent perennial ryegrass pasture similar to, but separate from, the 'ryegrass' treatment for 3 weeks in April when there was insufficient plantain. The ryegrass treatment comprised eight paddocks (3.73 ha in total), and the plantain treatment comprised three paddocks (1.9 ha plantain in total, plus 1.22 ha of ryegrass pasture in two paddocks). During the experiment, including rotations, 7.08 ha of the ryegrass treatment and 5.89 ha of plantain was grazed. Fortnightly liveweight measurements were taken for calculation of liveweight gain. At the conclusion of the trial, liver $\mathrm{Cu}$ concentration, blood Se and serum vitamin B12 were determined.

\section{Experiment 3}

From mid-October 2004 to mid January 2005, red deer hinds and their calves were allocated to rotationally grazing permanent perennial ryegrass-based pasture only, or intermittently grazing both plantain ( $26 \%$ of the time) and permanent ryegrass pasture ( $74 \%$ of the time), used in previous experiments. Hinds had previously only grazed permanent pasture for the duration of pregnancy. Hinds were fed ad-libitum according to visual assessment of pre- and post-grazing herbage mass, with post-grazing herbage mass remaining above $1700( \pm 200) \mathrm{kg} \mathrm{DM} / \mathrm{ha}$. At the conclusion of the trial on 12 January 2005, stag calves from each treatment group were randomly allocated based on liveweight to liver biopsy for determination of liver $\mathrm{Cu}$ concentration $(\mathrm{n}=10)$ and vitamin B12 concentration $(\mathrm{n}=5)$.

\section{Laboratory analysis}

Samples of liver, blood and serum were analysed for trace elements by Gribbles Veterinary Pathology (Expt. 1) and New Zealand Veterinary Pathology (Expts. 2 \& 3). Forage mineral content was determined by plasma emission spectroscopy (Spectrachem Ltd and AgResearch Ltd) for Experiment 1 and by ICP-MS (Hills Laboratories, Hamilton) for Experiment 2. Forage chemical composition was determined according to the methods described by Ramirez-Restrepo et al. (2005). Organic matter digestibility was estimated by in vitro enzymatic digestion (Roughan \& Holland 1977) for Experiment 2.

\section{Statistical analysis}

Final liveweight, average liveweight gain and carcass weight data from Experiment 1 were analysed using the GLM ANOVA procedure (SAS 1998). Forage composition, average liveweight gain and mineral status at the conclusion of Experiment 2 and mineral status from Experiment 3 were analysed by GLM ANOVA procedure (Genstat 5, 3.2, Lawes Agricultural Trust, 1996). Forage mineral data from Experiment 1 were analysed using the mixed model procedure in SAS (SAS 1998). Values reported are least square means (LSM), with standard error of the mean (SEM). Significance was declared at $\mathrm{P}<0.05$. All mean comparisons were by Fisher's least significant difference method after a significant main effect of treatment was detected.

\section{Results}

For spring forages grazed in Experiment 1, ryegrass pasture had the highest iron and molybdenum and lowest copper content; chicory had the highest copper content and plantain was highest in cobalt (Table 1). The organic matter and gross energy content of all forages was similar. However, the nitrogen content of plantain was low compared with the other forages. For Experiment 2 in autumn, the organic matter digestibility and copper content 
Table 1 Chemical composition (\% dry matter) and mineral content ( $\mathrm{mg} / \mathrm{kg}$ freeze dried herbage) of minerals in perennial ryegrass-based pasture (ryegrass), chicory and plantain feed on offer to weaner deer during Experiments 1 (spring 2003) and 2 (autumn 2004).

\begin{tabular}{|c|c|c|c|c|}
\hline & Ryegrass & Chicory & Plantain & SEM \\
\hline Spring 2003 & $n=1$ pooled & $n=1$ pooled & $n=1$ pooled & \\
\hline Organic matter & 79 & 77 & 77 & - \\
\hline Gross energy $\mathrm{MJ} / \mathrm{kg}$ & 16.1 & 15.9 & 15.5 & - \\
\hline Nitrogen & 2.4 & 2.8 & 1.7 & - \\
\hline Cobalt & 0.19 & 0.14 & 0.28 & - \\
\hline Copper & 6.1 & 8.4 & 6.3 & - \\
\hline Iron & 499 & 270 & 407 & - \\
\hline Molybdenum & 0.48 & 0.20 & 0.18 & - \\
\hline Autumn 2004 & $n=3$ & - & $n=3$ & \\
\hline Organic matter & 83 & - & 82 & 2.1 \\
\hline Organic matter digestibility $\%$ & 64.1 & - & 74.2 & $0.73^{* *}$ \\
\hline Gross energy MJ/kg & 16.7 & - & 16.8 & 0.40 \\
\hline Nitrogen & 2.8 & - & 3.1 & 0.16 \\
\hline Cobalt & 0.35 & - & 0.36 & 0.118 \\
\hline Copper & 9.3 & - & 14.0 & $0.75^{*}$ \\
\hline Iron & 1271 & - & 795 & 383.6 \\
\hline Molybdenum & 0.31 & - & 0.34 & 0.042 \\
\hline Selenium & 0.037 & - & 0.057 & 0.0088 \\
\hline
\end{tabular}

"Statistically significant difference between forages within rows, " $\mathrm{P}<0.05$, " $\mathrm{P}<0.01$.

Table 2 Pre- and post-grazing herbage mass, mean liveweight gain (LWG), final liveweight (LW) and carcass weight $(\mathrm{CW})$ of weaner deer grazing perennial ryegrass-based pasture (ryegrass), chicory or plantain for 8 weeks prior to slaughter in December 2003 (Experiment 1) and liveweight gain of weaner deer grazing pasture or plantain during autumn 2004 (Experiment 2).

\begin{tabular}{|c|c|c|c|c|}
\hline & Ryegrass & Chicory & Plantain & \\
\hline \multicolumn{4}{|l|}{ Herbage mass (kg DM/ha) } & SD \\
\hline Exp. 1: pre-graze & 2809 & 3879 & 4158 & 1357.7 \\
\hline Exp. 1: post-graze & 3142 & 3347 & 3605 & 1011.5 \\
\hline Exp. 2: pre-graze & 3769 & - & 2824 & 773.3 \\
\hline Exp. 2: post-graze & 2677 & - & 1935 & 606.8 \\
\hline \multicolumn{4}{|c|}{ Liveweight gain and venison production } & SEM \\
\hline $\operatorname{Exp~1:~LWG~}(\mathrm{g} / \mathrm{d})$ & $217^{a}$ & $303^{b}$ & $204^{a}$ & $19.0^{* *}$ \\
\hline Exp 1: Final LW $(\mathrm{kg})^{1}$ & $86^{a}$ & $91^{\mathrm{b}}$ & $85^{\mathrm{a}}$ & $1.34^{*}$ \\
\hline Exp 1: CW (kg) & $47.6^{\mathrm{a}}$ & $51.3^{\mathrm{b}}$ & $45.2^{\mathrm{a}}$ & $1.40^{*}$ \\
\hline Exp 2: LWG $(\mathrm{g} / \mathrm{d})^{1}$ & $158^{a}$ & - & $180^{\mathrm{b}}$ & $2.0^{* *}$ \\
\hline Exp 2: Final LW $(\mathrm{kg})^{1}$ & $61^{a}$ & - & $64^{\mathrm{b}}$ & $6.0^{* *}$ \\
\hline
\end{tabular}

of ryegrass pasture was significantly lower compared with plantain, while the organic matter, gross energy content, nitrogen, cobalt, iron and molybdenum content were similar (Table 1). Overall, it appeared that the nutritive value of ryegrass and plantain pastures grazed in spring during Experiment 1 were inferior to that grazed in autumn during Experiment 2.

Feeding value, determined by liveweight gain in Experiment 1, of chicory in spring was approximately $45 \%$ greater $(\mathrm{P}<0.01)$ compared with ryegrass pasture and plantain, which had similar feeding value (Table 2 ). After 8 weeks of grazing, this difference in feeding value resulted in the mean carcass weight of chicory-grazed deer being $10 \%$ heavier $(\mathrm{P}<0.05)$ than for ryegrass or plantain-grazed deer. In Experiment 2, during autumn, the feeding value of plantain was approximately $14 \%$ greater $(\mathrm{P}<0.05)$ than ryegrass pasture.

Table 3 shows that initially, liver copper, serum B12 and blood selenium status of the treatment groups in Experiment 1 were similar. At slaughter, liver copper concentrations from ryegrass-fed deer were significantly lower $(\mathrm{P}<0.05)$ compared with chicory-fed deer. Liver copper concentrations of plantain-fed deer were intermediate between ryegrass- and chicory-fed deer and 
Table 3 Mean liver copper (Cu), liver and serum vitamin B12 and blood selenium (Se) status of weaner deer grazing perennial ryegrass-based pasture (ryegrass), chicory or plantain for 8 weeks prior to slaughter in December 2003 (Experiment 1), grazing pasture or plantain during autumn 2004 (Experiment 2) and of calves grazing ryegrass only or ryegrass plus plantain with their dams from October 2004-January 2005 (Experiment 3).

\begin{tabular}{|c|c|c|c|c|}
\hline & Ryegrass & Chicory & Plantain & SEM \\
\hline \multicolumn{5}{|c|}{ Liver Cu concentration $(\mu \mathrm{mol} / \mathrm{kg})$} \\
\hline Exp. 1 Initial & 97 & 89 & 90 & 19.3 \\
\hline Exp. 1 Final & $81^{a}$ & $299^{b}$ & $166^{\mathrm{ab}}$ & $42.0^{*}$ \\
\hline Exp. 2 Final & $183^{a}$ & - & $500^{b}$ & $57.1^{* *+}$ \\
\hline Exp. 3 Final & 222 & - & $264^{1}$ & 50.0 \\
\hline \multicolumn{5}{|c|}{ Serum B12 concentration (pmol/L) } \\
\hline Exp. 1 Initial & 83 & 98 & 118 & 29.4 \\
\hline Exp. 1 Final & $101^{a}$ & $148^{a}$ & $246^{\mathrm{b}}$ & $31.7^{\prime *}$ \\
\hline Exp. 2 Final & $120^{\mathrm{a}}$ & - & $149^{b}$ & $4.8^{4+*}$ \\
\hline \multicolumn{5}{|c|}{ Liver B12 concentration (nmol/kg) } \\
\hline \multicolumn{5}{|c|}{ Blood Se concentration (nmol/L) } \\
\hline Exp. 1 Initial & 295 & 252 & 328 & 18.2 \\
\hline Exp. 1 Final & $279^{a}$ & $205^{a}$ & $377^{\mathrm{b}}$ & $20.1^{*}$ \\
\hline Exp. 2 Final & $314^{a}$ & - & $467^{b}$ & $18.4^{\prime \prime *}$ \\
\hline
\end{tabular}

did not differ significantly from either. At the conclusion of Experiment 1, 90\% of deer fed ryegrass, $0 \%$ of deer fed chicory and $30 \%$ of deer fed plantain were in the "at risk" range for clinical copper deficiency $(<60 \mu \mathrm{mol} / \mathrm{kg})$. At the conclusion of Experiment 2, deer grazing ryegrass had a significantly lower copper status than deer grazing plantain $(\mathrm{P}<0.001)$. Forage grazed by hinds with calves at foot did not significantly affect liver copper status of calves in Experiment 3.

At the conclusion of Experiment 1, the serum B12 status of deer grazing plantain was significantly greater than at the trial initiation and also greater when compared with deer grazing other forages $(\mathrm{P}<0.05)$ (Table 3 ). In Experiments 2 and 3, deer grazing pasture had significantly lower serum and liver B12 concentrations, respectively, compared with deer grazing plantain $(\mathrm{P}<0.01)$. Blood selenium concentrations of deer grazing plantain were also significantly enhanced compared with deer grazing ryegrass and/or chicory $(\mathrm{P}<0.05)$ at the conclusion of Experiments 1 and 2.

\section{Discussion}

This is the first report describing the feeding value of plantain for farmed deer. Unlike chicory, which was able to increase the carcass weight of weaner deer by $10 \%$ after just 8 weeks grazing, it appears that plantain offered little advantage over perennial ryegrass-based pastures for weaner deer growth in spring, probably due to its propensity to "bolt" into reproductive development (Sanderson et al. 2003), which reduces its digestibility
(Swainson \& Hoskin 2006). This study suggests that plantain offers its best advantage for weaner deer growth over perennial ryegrass-based pasture in autumn, when a 14\% advantage in liveweight gain resulted from grazing plantain compared with pasture. Further research needs to be conducted to evaluate the net carcass gain and hence real financial return from grazing alternative forage species for venison production at different times of the year.

As the reproductive stem and dead matter content of forages increases during spring, fibre and lignin content and hence digestibility, feed intake and overall feeding value decreases. Therefore control of plantain swards in late spring by mechanical topping or grazing with other stock following weaner deer is likely to be important in maintaining feeding value, as is the case with chicory during summer.

Another factor which can increase the feeding value of mixed swards is the legume content. Both of the forage herbs used in the current experiments was initially sown as a pure sward, but over time a white clover population established naturally and increased as a proportion of the sward for both chicory and plantain. The legume content was 14 times higher in chicory swards than in ryegrass and plantain swards in Experiment 1, and similarly higher in plantain compared with ryegrass grazed during autumn in Experiment 2. The combination of a higher legume content and lack of fibrous reproductive stems in plantain grazed in autumn compared with spring may partly explain the relative differences in feeding value of 
plantain and ryegrass observed between the two seasons. However, further research is needed to understand the effect on digestibility and feeding value of seasonal changes in secondary, anti-nutritional compounds present in plantain and to optimise grazing management of specialist forages by farmed deer to maximise both nutritive value and forage production and longevity of the sward.

This study has highlighted the complementary role of both chicory and plantain in maintaining trace element status of deer and demonstrated for the first time that forage plantain can enhance the copper, vitamin B12 and selenium status of deer. Evidence from the present and previous studies (Barry et al. 2001; Wilson et al. 2003) suggests that chicory is likely to have a greater role in maintaining copper status than plantain given its higher copper concentration. It is not known whether the higher concentration of molybdenum and iron in ryegrass pasture compared with the forage herbs was enough to have reduced copper absorption in this group.

Vitamin B12 and selenium status of ruminants is related to the cobalt, and selenium content of the diet, respectively. However, no robust reference values or relationships between dietary cobalt and selenium intake and animal requirements have been established for deer (Grace \& Wilson 2002). All animals appeared to have adequate selenium status at all times, if reference values for sheep are used as an approximation for deer.

During the spring trial, the cobalt content of plantain was approximately twice that of both ryegrass and chicory, whereas, during the following autumn, ryegrass and plantain had a similar cobalt content. Yet a significantly higher vitamin B12 status was found in deer grazing plantain compared with ryegrass during both seasons, in contrast to lambs grazing plantain in summer where copper and selenium status was enhanced, but not vitamin B12 (Moorhead et al. 2002). The present autumn result could have been due to a higher dry matter intake for deer grazing plantain compared with ryegrass. However, in addition to mineral intake, bioavailability of minerals may differ between forages and this needs further investigation. Also, due to influences of soil chemistry and $\mathrm{pH}$ on trace mineral status of plants, data cannot be extrapolated from the present trial to other environments.

In conclusion, trace element supply and health of farmed deer are likely to be enhanced when forage mixes contain both plantain and chicory. However, the need for, and effectiveness of, trace element supplementation must be determined by regular monitoring. When considering forage herbs for use in venison production systems, growth rates of young deer were in the order of chicory $>$ plantain $\geq$ ryegrass, so for maximum deer growth a chicory-dominant sward is required. However, the role of legumes in herb swards may also be important for optimising feeding value of the sward as a whole. The feeding value of plantain can probably only exceed that of ryegrass in spring if the reproductive development is controlled by regular rotational grazing and/or mechanical topping.

\section{ACKNOWLEDGEMENTS}

Mr G. Purchas is thanked for technical assistance. The H.B. Williams Turanga Trust, Massey University Agricultural Research Foundation, DEEResearch Postgraduate Fund, Wrightsons Seeds Ltd and Agricom Ltd provided funding. Mrs A. Quinn, Mr G. Tattersfield, Miss N. Swainson, Dr A. Ayanegui-Alcerreca and Miss F. Castillo are thanked for assistance with biopsies and blood sampling.

\section{REFERENCES}

Barry, T.N. 1998. The feeding value of chicory (Cichorium intybus) for ruminant livestock: a review. Journal of Agricultural Science, Cambridge 131: 251261.

Barry, T.N.; Molan, A.L.; Wilson, P.R.; Lopez-Villalobos, N.; Schreurs, N.M.; Duncan, A.J. 2001. Chicory as an alternative forage for deer health. Pp 122-127 In: Proceedings of a Deer Course for Veterinarians No 18, Ed. P.R. Wilson, Deer Branch of the New Zealand Veterinary Association.

Grace, N.D.; Wilson, P.R. 2002. Trace element metabolism, dietary requirements, diagnosis and prevention of deficiencies of deer. New Zealand Veterinary Journal 50: 252-259.

Moorehead, A.J.E.; Judson, H.G.; Stewart, A.V. 2002. Liveweight gain of lambs grazing 'Ceres Tonic' plantain (Plantago lanceolata) or perennial ryegrass (Lolium perenne). Proceedings of the New Zealand Society of Animal Production 62:171-173.

Ramirez-Restrepo, C.A.; Barry, T.N.; Lopez-Villalobos, N.; Kemp, P.D.; Harvey, T.G. 2005. Use of Lotus corniculatus containing condensed tannins to increase reproductive efficiency in ewes under commercial dryland farming conditions. Animal Feed Science and Technology 121: 23-34.

Reid, T.C.; McAllum, H.; Johnston, P.D. 1980. Liver copper concentrations in farmed deer (Cervus elaphus) and wapiti (Cervus canadensis) in New Zealand. Research in Veterinary Science 28: 262-264.

Roughan, P.G.; Holland, R. 1977. Predicting the in-vitro digestibilities of herbages by exhaustive enzymatic hydrolysis of cell walls. Journal of the Science of Food and Agriculture 28: 1057-1064.

Sanderson, M.A.; Labreveux, M.; Hall, M.H.; Elwinger, G.F. 2003. Nutritive value of chicory and English forage plantain. Crop Science 43: 1797-1804.

Swainson, N.M.; Hoskin, S.O. 2006. Apparent 
digestibility and rumen fermentation of fresh plantain (Plantago lanceolata cv Ceres Tonic) and perennial ryegrass (Lolium perenne cv Nui) -based pasture fed to red deer (Cervus elaphus). Proceedings of the New Zealand Society of Animal Production 66: 64-69.

Tremaine-Boon, S.; Hart, J.C.A.; Wilson, P.R.; LopezVillalobos, N. 2002. Liver trace element concentrations in farmed and feral red deer (Cervus elaphus). New Zealand Veterinary Journal 50: 111-114.
Wilson, P.R. 2000. A liver biopsy technique for deer. In: Proceedings of a trace element workshop. Veterinary Continuing Education Foundation. Massey University, Palmerston North.

Wilson, P.R.; Barry, T.N.; Quinn, A.; Lopez-Villalobos, N.; Grace, N.D. 2003. Trace element status of deer related to diet. Pp 122-127 In: Proceedings of a Deer Course for Veterinarians No 20, Ed. P.R. Wilson, Deer Branch of the New Zealand Veterinary Association. 